\title{
PEMILIHAN SUPPLIER TERBAIK PENYEDIA BARANG CONSUMABLE MENGGUNAKAN METODE ANALYTICAL HIERARCHY PROCESS (Studi kasus di Departemen Pengadaan Barang PT. PUSRI)
}

\section{THE BEST SUPPLIER SELECTION OF CONSUMABLE GOODS SUPPLIER USING ANALYTICAL HIERARCHY PROCESS METHOD \\ (Case Study at Procurement Department of PT. PUSRI)}

\section{Irnanda Pratiwi ${ }^{1}$, Hermanto $\mathrm{MZ}^{2}$ dan Selvia Aprilyanti ${ }^{3 .}$} Universitas Tridinanti Palembang, Jalan Kapten Marzuki No.2446, Palembang, 301 29, Indonesia

[1]nanda101084@gmail.com [3] selvia1704@univ-tridinanti.ac.id

Diterima: 05062018

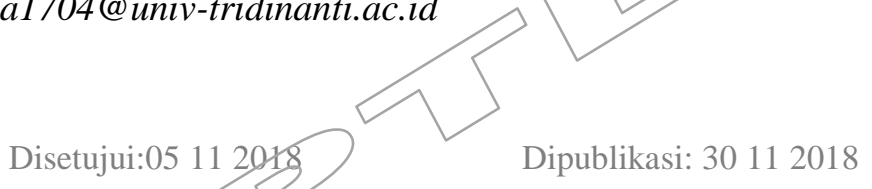

Pemilihan supplier adalah salah satu hal yang sangat penting dalam aktifitas pengadaan barang atau jasa bagi perusahaan. Salah satu metode yang dapat digunakan dalan pemilihan supplier adalah Analitycal Hierarchy Process (AHP). Penelitian ini dilakukan di Departemen Pengadaan Barang PT. PUSRI. Penelitian ini fokus kepada supplier penyedia barang consumable karena pengadaan barang ini paling sering dilakukan. Sampel dari penelitian ini adalah karyawan di lingkungan Departemen pengadaan barang yang menghandle pembelian barang consumable. Dari Hasil Penelitian tingkat kepentingan kriteria menghasilkan bobot sebagai berikut: Prioritas I Harga (0,42), Prioritas II Kualitas (0,33), Prioritas III Respon (0, 11) serta Prioritas W pengirinan dan costumer care (0,07). Bobot keseluruhan (Global Priority) supplier terbaik adalah PT. Kokai Indo Abadi 10,47). Berdasarkan penelitian dapat disimpulkan bahwa PT. Kokai Indo Abadi adalah perusahaan yang paling konsisten dalam pengadaan barang consumable sehingga dapat diikutkan dalam tender selanjutnya.

Kata Kunci: Analitycal Hierarchy Process (AHP), Barang Consumable, Pemilihan Supplier, Supplier Terbaik,

\section{ABSTRACT}

Supplier selection is one of the most important activity of company's procurement of goods and services function. One of the methods that can be used is Analytical Hierarchy Process (AHP). This research was conducted in Procurement Department of PT. PUSRI Palembang. This study focuses on suppliers of consumable goods because this goods most often purchased. The sample of the research were the employees in the department of goods procurement that handle the purchase 
of consumable goods. The final result of relative importance's supplier selection criteria was found :First Priority is Price $(0,42)$, Second Priority is Quality (0,33), Third Priority is Response $(0,11)$ and Fourth Priority is Delivery $(0,09)$ and last priority is customer care (0,08). The fisrt priority supplier is PT. Kokai Indo Abadi (0.47). The result of this study that PT. Kokai Indo Abadi is the most consistent company in the procurement of consumable goods so it can be included in the next auction.

Keywords: Supplier Selection, Analitycal Hierarchy Process (AHP), Best Supplier, Consumable goods

\section{PENDAHULUAN}

Pemilihan supplier yang kompeten dan mampu memberikan bahan baku berkualitas merupakan langkah awal untuk menjaga kualitas produk. Dalam usaha untuk memenuhi kebutuhan perusahaan secara konsisten dan berkualitas, pemilihan supplier perlu dilakukan untuk mendapatkan kriteria - kriteria yang sesuai bagi perusahaan (Ngatawi \& Setyaningsih, 2011). Perusahaan manufaktur mempunyai hubungan dengan banyak pihak, salah satunya adalah supplier. Supplier adalah perusahaan yang menyediakan material yang tidak bisa disediakan oleh perusahaan manufaktur itu sendiri (Prasetyo \& Kurniati, 2017)

Perusahaan sering tidak mendapat supplier terbaik dikarenakan hingga sekarang, banyak perusahaan, baik manufaktur ataupun jasa yang menentukan supplier tersebut berdasarkan intuisí dan hubungan relasi, namun tidak disertai dengan kriteria dan metode evaluasi yang rasional dan terukur (Mario dkk, 2015).

PT Pupuk Sriwidjaja Palembang (PUSRI) yang berdiri pada tanggal 24 Desember 1959 di Palembang, merupakan perusahaan pelopor yang memproduksi pupuk $>$ urea di Indonesia. Dalam menjaga tingkat produksi agar selalu tepat sesuai target maka diperlukan sparepart pendukung kegiatan operasi yang bertujuan agar mendukung kinerja pabrik. Dalam pengadaan sparepart tersebut dilakukan oleh Divisi Pengadaan logistik. Dalam proses bisnis, aktifitas logistik sangat berperan penting untuk menyalurkan produk dari produsen ke konsumen. Maka dari itu, banyak perusahaan perusahaan yang memilih untuk mengembangkan usahanya di bidang pelayanan jasa logistik. Namun, dari semua perusahaan penyedia jasa logistik memiliki kelebihan dan kekurangan masing - masing (Astuti \& Fatma, 2017).

Pengadaan logistik merupakan kegiatan untuk menyediakan bahan baku produksi, maupun bahan penunjang operasional yang disesuaikan dengan kebutuhan perusahaan tersebut. Jenis barang, jumlah maupun harga dan sumbernya dapat di pertanggungjawabkan. Tender itu sendiri memiliki dua jenis yaitu secara konvensional atau manual melalui SAP dan secara Elektronik atau sering disebut e-procurement.

Supply Chain Management (SCM) atau manajemen rantai pasok merupakan kegiatan pengelolaan yang bertujuan untuk mendapatkan bahan baku, mentransformasikar bahan baku untuk menjadi barang setengah jadi atau barang jadi serta mendistribusikan barang - barang tersebut hingga sampai ke tangan konsumen (Render \& Heizer, 2016). Lahirny a konsep lean manufacturing yang berakar pada prinsip lean thinking yang telah merubain paradigma produksi dalam industri manufaktur sangat berkaitan erat dengan konsep supply chain (Putri, 2017).

Di dalam suatu rantai pasokan, perusahaan harus dapat mengoptimalisasi penggunaan waktu, lokasi, dan kuantitas barang. Pada umumnya kriteria yang dipertimbangkan di dalam proses supplier selection adalah kualitas, harga, pengiriman, dan service. Pemilihan supplier merupakan kegiatan yang penting bagi manajemen perusahaan, khususnya bila pemasok tersebut akan memasok barang yang sifatnya kritis atau akan digunakan dalam waktu lama sebagai pemasok penting.

Kriteria - kriteria yang digunakan dalam pemilihan supplier merupakan hal yang penting yang dapat mencerminkan strategi rantai pasok maupun karakteristik dari barang yang akan dipasok (Pujawan \& Er, 2017).

Pada saat ini perusahaan manufaktur maupun jasa harus memperhatikan elemen di luar perusahaan dalam penerapan konsep sistem produksi dan operasinya. Dengan kata lain, perusahaan harus mulai memperhatikan pengelolaan elemen supplier dan konsumen selain daripada mengelola elemen input, proses transformasi maupun output sebagai nilai tambah bagi konsumen. 
Pada penelitian ini, pemilihan kriteria pada supplier penyedia barang consumable, dimana belum pernah ada penelitian dalam memilih supplier tersebut. Kriteria dikelompokkan ke dalam 5 kriteria umum, yaitu harga, pengiriman, respon dan customer care. Dari lima kriteria tersebut terbagi lagi ke dalam kriteria-kriteria yang lebih spesifik. Dalam proses supplier selection bukan hanya kriteria kualitatif saja yang dipertimbangkan, kriteria kuantitatif juga dipertimbangkan.

Berdasarkan wawancara dan hasil observasi awal peneliti, masalah yang sering timbul adalah seringnya tender ulang atau tender tidak mencukupi syarat sah tender dikarenakan kurang tepat pemilihan supplier yang akan diundang, terutama untuk pengadaan barang yang bersifat rutin yaitu barang consumable. Kegiatan tender ulang ini juga akan mengeluarkan biaya ulang bagi perusahaan yang dapat bernilai $\pm 0,01 \%$ dari nilai lelang. Material Consumable merupakan bahan atau material habis pakai atau bahan - bahan yang bersifat tidak memiliki kemungkinan untuk diperbaiki atau digunakan kembali. Maksud dari pengertian consumable ini, dapat diartikan bahwa material rutin diantaranya welding electrode, valve, valve glove dan valve gate. Dari penelitian ini diharapkan dapat memberikan solusi perusahaan dalam pengambilan keputusan dalam penentuan kriteria supplier.

Secara pengertian, keputusan adalah proses perumusan penyelesaian tentang suatu masalah yang berawal dari penentuan latar belakang, mengidentifikasikan permasalanan hingga dihasilkannya suatu kesimpulan dan saran (Fahmi, 2016). Adanya kendala-kendala keputusan biasanya dikarenakan oleh subjek pengambil keputusan dalam suatu perusahraan sering menghadapi beberapa tindakan yang harus dilakukan. Ada dua komponen utama yang diidentifikasi dalam menyelesaikan persoalan yang berkaitan dengan pengambilan keputusan yaitu (Dimyati \& Dimyati, 2016) :

1. Objective (tujuan)

2. Variabel - variabel

Teknik pengambilan keputusan merupakan hal yang sangat penting dilakukan oleh perusahaan, dikarenakan semakin banyaknya kriteria yang diinginkan oleh perusahaan untuk memilih supplier. Tentunya hal ini akan membuat semakin rumit bagi perusahaan (Rimatho dkk, 2017)
Proses pemilihan supplier akan menjadi sederhana apabila hanya ada satu kriteria yang dipertimbangkan di dalam proses pengambilan keputusan. Meskipun dalam beberapa situasi, bagian purchasing harus membuat rangking atas kriteria yang dipertimbangkan. Secara umum perusahaan akan menggunakan pemilihan multiple criteria supplier dalam pengambilan keputusannya. Kriteriakriteria didalam pemilihan supplier membantu perusahaan dalam mengidentifikasi dan mengevaluasi supplier yang mampu menyediakan kualitas produk yang sempurna, cost rendah, ketersediaan, dan pengantaran yang konsisten.

Tujuan Penelitian ini diharapkan menjadi alternatif dalam pemilihan supplier barang consumable dengan kriteria yang menjadi prioritas pertimbangan departemen pengadaan barang dalam memilih supplier barang consumable sekaligus mengetahui best supplier barang consumable di departemen pengadaan barang dengan menggunakan metode Analytical Hierarchy Rrocess.

Pendekatan hirarki yang cukup sering digunakan dalam penentuan keputusan dikenal dengan metode Analytical Hierarchy Process (AHP). AHP merupakan salah satu bentuk pemilihan keputusan yang memungkinkan penggunanya untuk Tinembentuk pendapat dan memberikan batasan terhadap permasalahan melalui perkiraan atau dugaan dan menghasilkan penyelesaian masalah yang diinginkan (Saaty \& Vargas, 2012). Dengan kata lain, metode ini dianggap sebagai model multiobjective-multi-criteria.

\section{METODE PENELITIAN}

\subsection{Desain Penelitian}




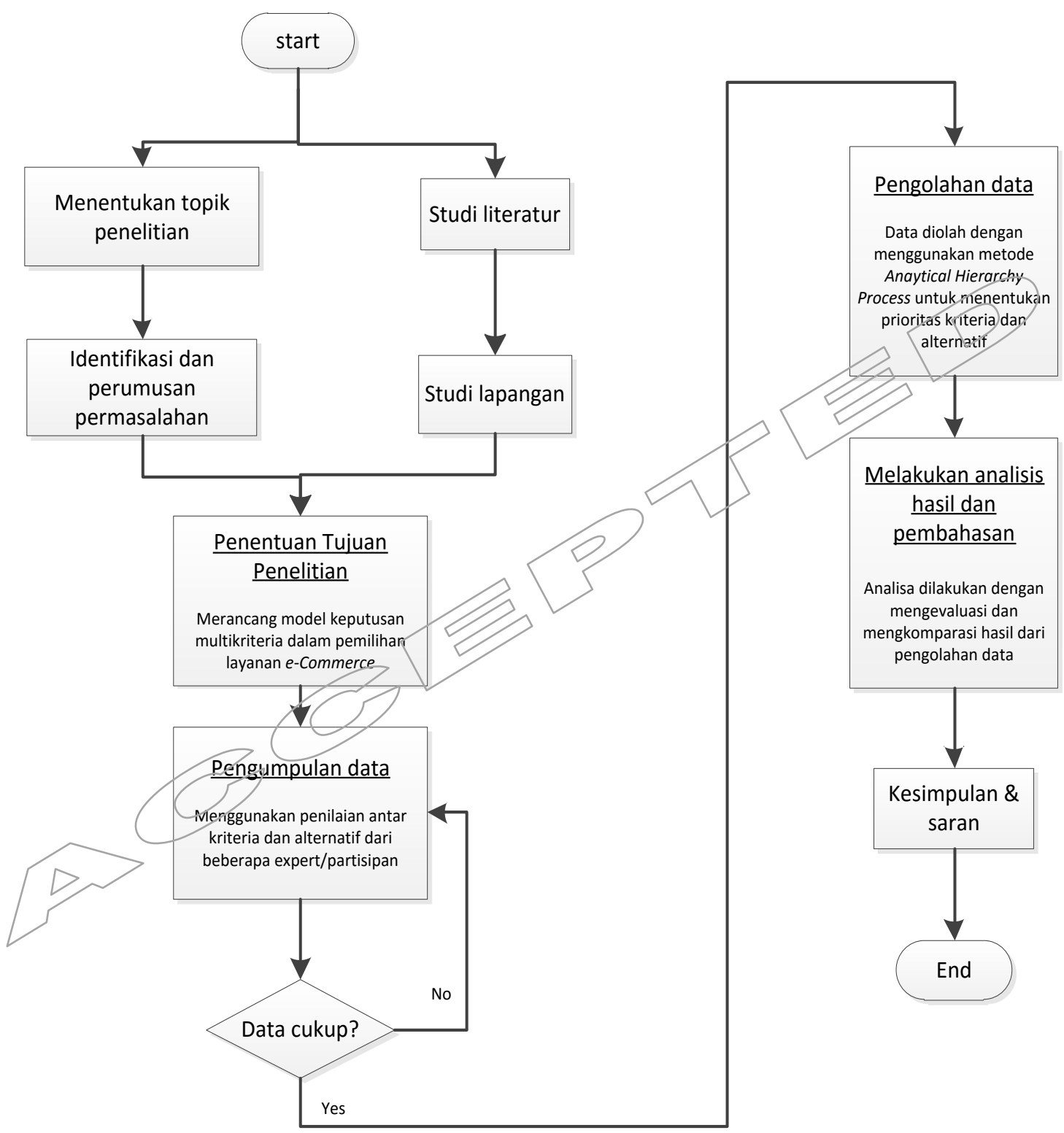

Gambar 1. Diagram Alir Penelitian

\subsection{Waktu dan Tempat}

Penelitian dilakukan di Departemen pengadaan barang PT. PUSRI Palembang dan waktu penelitian dilakukan selama satu bulan dari tanggal 01 Februari sampai dengan 28 Februari 2018.

\subsection{Instrumen Penelitian}

Data yang digunakan pada penelitian ini meliputi :
1. Data Primer, berupa kuesioner dan wawancara langsung terhadap karyawan yang memberikan penilaian terhadap supplier.

2. Data Sekunder, berupa data yang berasal dari data historis atau dokumen seperti dokumen penawaran vendor sebelumnya, data penawaran di sistem dan record performa vendor atau seseorang yang mendapat informasi dari sumber lain, serta dokumen lelang perusahaan. 


\subsection{Penilaian Responden / Expert}

Pada penelitian ini penilaian diberikan oleh (3) tiga orang karyawan yang sekaligus sebagai responden dalam penelitian ini. Karyawan yaing memberi penilaian adalah karyawan yang telah arau. pernah menangani dalam hal pembelian barang consumable yaitu Bapak Arestullah, Bapak Ismi Akbar dan Bapak Rendi. Pertanyaan yang diberikan melalui kuesioner kepada karyawan tersebut berkaitan tentang penilaian masing - masing terhadap kinerja supplier dalam memenuhi kewajibannya pada pengadaan barang di PT. PUSRI. 2.5 Pengolahan Data

Analisis sensitivitas metode Analytical Hierarchy Process $(A H P)$ bisa dilakukan secara perhitungan

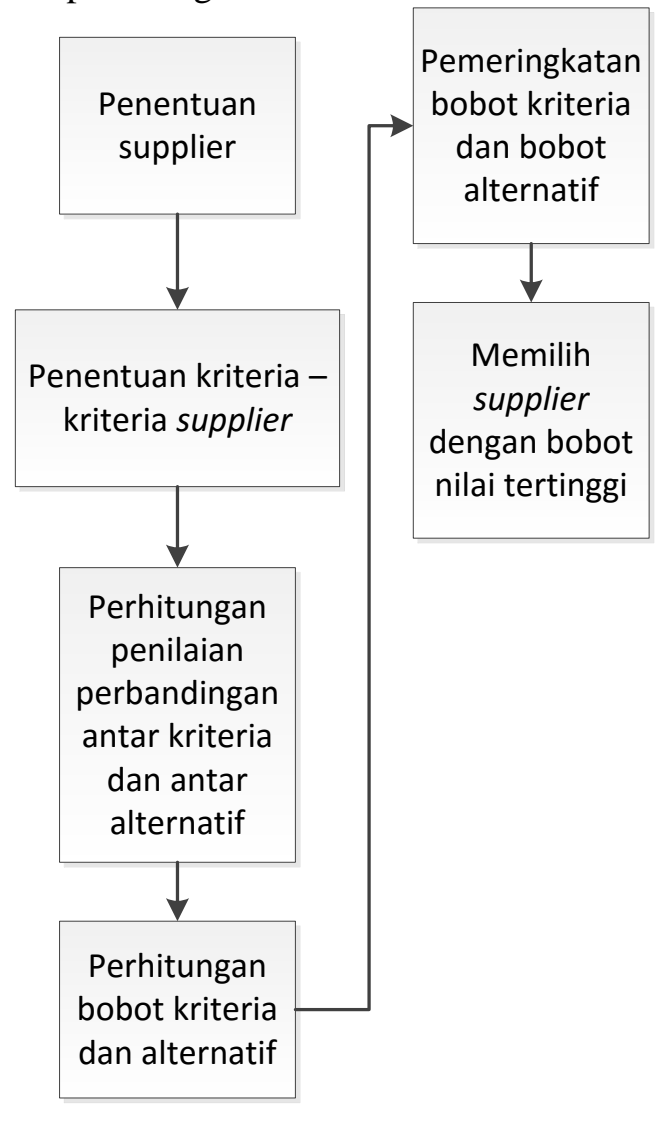

manlal atau menggunakan bantuan aplikasi perangkat lunak (software) Expert Choice untuk mengetahui seberapa jauh perubahan bobot kriteria utama dapat memberikan perubahan terhadap hasil pemilihan alternatif (Pratiwi, HAK, \& Erdiyansyah, 2014).

Pemilihan supplier melewati beberapa tahap, dimulai dari penentuan supplier mana saja yang akan menjadi alternatif pilihan, selanjutnya penentuan kriteria - kriteria supplier dan dilanjutkan dengan perhitungan bobot penilaian terhadap kriteria dan alternatif supplier. Diagram alir proses pemilihan supplier ditunjukkan pada Gambar 2.

Gambar 2. Diagram Alir Pemilihan Supplier

Adapun supplier yang menjadi objek adalah supplier yang kompeten dan kriteria serta subkriteria merupakan hasil dari wawancara dan penilaian responden seperti pada Gambar 3.
Penggunaan metode AHP dalam penelitian ini terbagi dalam 3 level. Level paling utama merupakan tujuan atau goal, yaitu memilih best supplier. Level di bawahnya yaitu level kedua merupakan level kriteria yang ditentukan berdasarkan persyaratan yang tercantum dalam dokumen lelang, adapun 
kriteria - kriteria yang maksud terdiri dari (Anonim, 2010) :

1. Harga,

2. Kualitas,

3. Waktu pengiriman,

4. Ketepatan jumlah,

5. Customer care.

Level paling bawah merupakan level alternatif, yang ditempati oleh supplier-supplier dari perusahaan, yaitu :

1. CV. Ditra Pratama

2. PT. Kokai Indo Abadi

3. PD. Sinar Bahagia

AHP berfungsi untuk memberikan penilaian terhadap faktor-faktor kualitatif yang dinyatakan secara subyektif. Skala penilaian yang diterapkan yaitu antara skala 1-9 seperti yang ditunjukkan pada Tabel 1.

Tabel 1. Skala Penilaian Perbandingan Berpasangan (Saaty \& Vargas, 2012)

\begin{tabular}{|c|c|}
\hline $\begin{array}{c}\text { Tingkat } \\
\text { Kepentingan }\end{array}$ & Definisi \\
\hline $\mathbf{1}$ & Sama Pentingnya \\
\hline 3 & $\begin{array}{l}\text { Agak lebih penting yang satu atas } \\
\text { lainnya }\end{array}$ \\
\hline 5 & Cukup penting \\
\hline 7 & Sangat penting \\
\hline 9 & Mutlak Lebih penting \\
\hline $2,4,6,8$ & $\begin{array}{l}\text { Nilai tengah diantara dua nilai } \\
\text { keputusan yang berdekatan }\end{array}$ \\
\hline Kebalikan & $\begin{array}{l}\text { Jika untuk aktivitas i mendapatkan } \\
\text { satu angka dibanding dengan } \\
\text { aktivitas j, maka j mempunyai nilai } \\
\text { kebalikan dari i }\end{array}$ \\
\hline
\end{tabular}

Mengumpulkan nilai perbandingan berpasangan dari wawancara responde
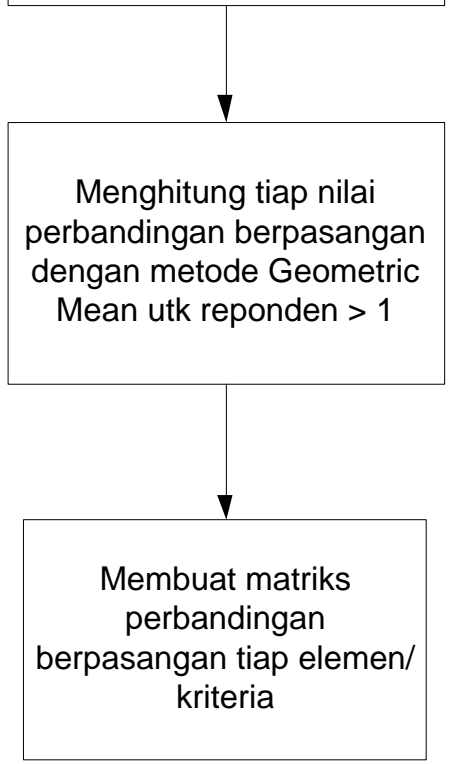

Gambar 4. Alur Penentukan matriks perbandingan berpasangan 


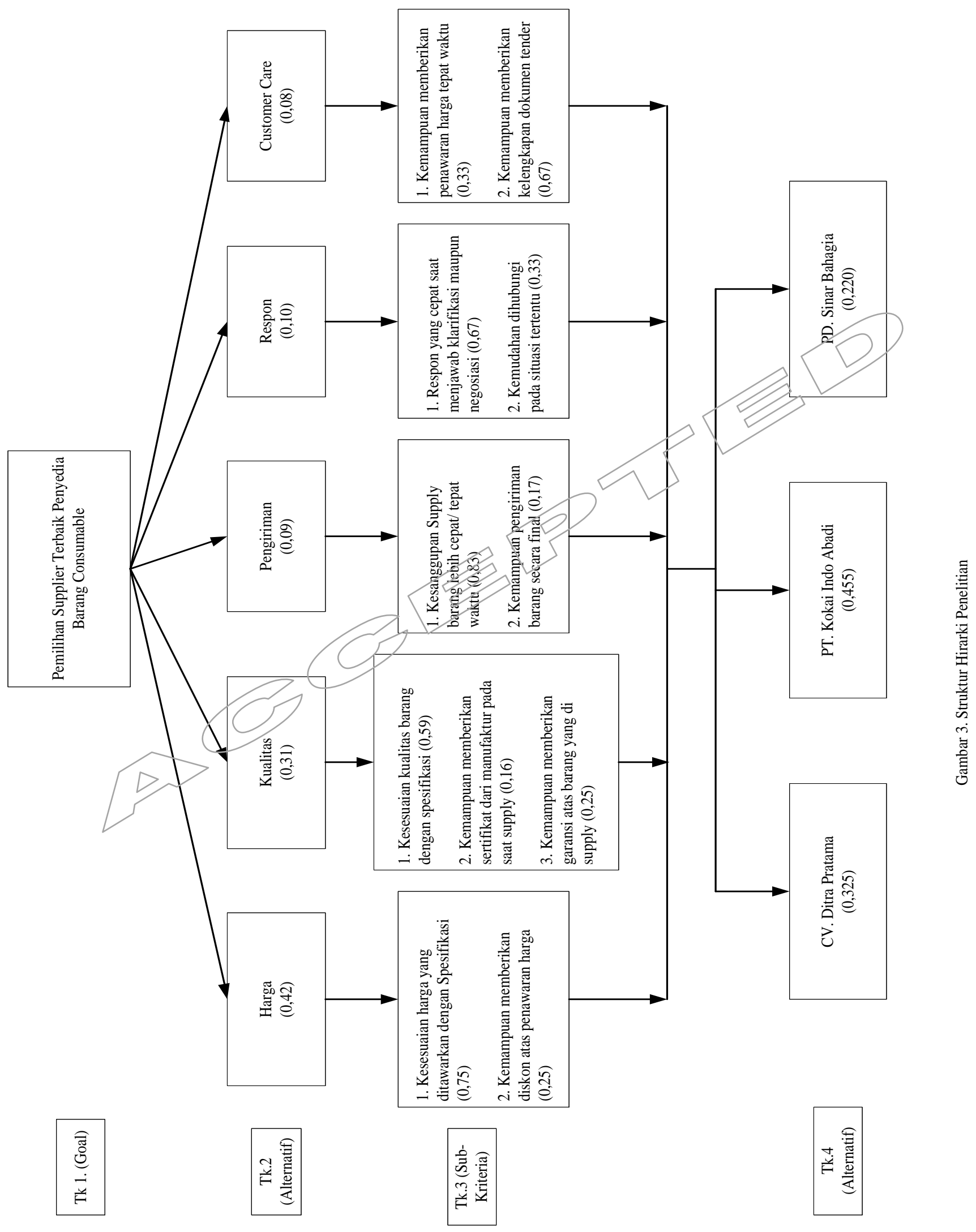


Penilaian ini diberikan dengan membandingkan antar elemen. Perbandingan tersebut dilakukan dengan memberikan skor.

Jumlah bobot kriteria untuk masing-masing keputusan dihitung menggunakan formulasi sebagai berikut:

1. Menentukan matrik perbandingan berpasangan (pairwise comparison).

Matrik ini menggambarkan pendapat seseorang tentang perbandingan tingkat kepentingan tiap elemen pada suatu hirarki terhadap elemen pada hirarki di atasnya. Kemungkinan akan adanya matriks pendapat individu berukuran $n \times n$ sebanyak $m$ buah untuk setiap partisipan jika jumlah elemen pada hirarki tersebut berupa $m$. Sehingga dibutuhkan sejumlah $\mathrm{n}(\mathrm{n}-1) / 2$ judgment sebagai penilaian dari partisipan. Hal ini ditunjukkan pada Gambar 4.

Pada matrik $\mathrm{a}_{\mathrm{ji}}$ menyatakan nilai matrik pendapat individu yang mencerminkan perbandingan kepentingan antara elemen ke-j dengan elemen ke-i pada hirarki yang sama dan bernilai $1 / a_{\mathrm{ij}}$. sedangkan ${ }_{\mathrm{ij}}$ menyatakan nilai matrik pendapat individu yang merupakan perbandingan kepentingan antara elemen ke-i dengan elemen ke-j pada suatu hirarki terhadap satu elemen pada hirarki diatasnya, Jika $\mathrm{i}=\mathrm{j}$ maka nilai aij $=1$. Jika indeks konsistensi lebih besar dari 1(konsistensi >1), maka perhitungan perbandingan berpasangan tersebut harus diulang. Batas toleransi nilai inkonsistensi adalah $\leq 10 \%$ atau 0,1 .

Tahapan-tahapan dalam menghitung indeks konsistensi secara berurutan dilakukan sebagai berikut:

a. Mengalikan nilai matriks perbandingan awal dengan bobot.

b. Mengalikan jumlah baris dengan bobot.

c. Menghitung nilai $\lambda$ maks.

d. Menghitung CI (Consistensi Index), dengan rumus:

$$
C I=\frac{\lambda_{\max }-n}{n-1}
$$

e. Menghitung nilai Consistensi Ratio (CR), dengan rumus:

$$
C R=\frac{C I}{R I}
$$

dengan ketentuan nilai random index ditunjukkan pada Tabel 2.

Tabel 2. Random Consistency Index (RI) (Saaty \& Vargas, 2012)

\begin{tabular}{cccccccccc}
\hline $\mathrm{N}$ & 1 & 2 & 3 & 4 & 5 & 6 & 7 & 8 \\
\hline $\mathrm{RI}$ & 0,00 & 0,00 & 0,58 & 0,90 & 1,12 & 1,24 & 1,32 & 1,41 \\
\hline \multicolumn{4}{c}{ di } \\
\multicolumn{4}{c}{ bergantung pada jumlah ordo matriks $n}$.
\end{tabular}

2. Menormalkan setiap kolom elemen berpasangan antar kriteria dengan cara membagi masing-masing elemen matriks dengan jumlah kolom. Selanjutnya dihitung bobot elemennya yang merupakan rata-rata jumlah nilai elemen baris matriks perbaidingan yang telah dinormalkan.

$$
a_{i j}=\frac{a_{i j}}{\max _{a_{i j}}}
$$

3. Untuk mencari Priority Vector yaitu dengan caramenjumlahkan nilai pada setiap kolom ke$i$ yaitu :

$$
a_{i j}=\sum_{i} a_{i j}
$$

4. Bobot untuk setiap kriteria didapat dengan membagi jumlah nilai setiap kolom dengan $n$ sejumlah kriteria yang dibandingkan.

$$
W i=\frac{a_{i}}{n}
$$

\section{HASIL DAN PEMBAHASAN}

Data yang digunakan untuk mengukur prioritas kepentingan dari subkriteria pada tiap kriteria dalam memilih supplier didapatkan dari kuesioner yang disebar kepada 3 orang responden di lingkungan departemen pengadaan barang PT. PUSRI Palembang. Analisis data dilakukan dengan menyatukan pendapat dari beberapa responden, jika pendapat diberikan dari multi expert, maka nilai perbandingan diperoleh dengan persamaan Geometric Mean (Clemen \& Reilly, 2013), yaitu : 


$$
G=\left(\prod_{i=1}^{n} X_{i}\right)^{1 / n}
$$

Dimana :

$\mathrm{G}=$ Geometric Mean (rata - rata geometrik)

$\mathrm{n}=$ jumlah variabel

$\mathrm{x}=$ nilai setiap expert

$\mathrm{i}=1,2,3 \ldots \mathrm{dst}$

Metode pairwise comparison dilakukan dengan cara membandingkan tiap kriteria yang memiliki sifat homogen secara berpasangan sehingga akan lebih mudah dan objektif untuk menentukan kriteria yang lebih baik nilainya (Andalia \& Pratiwi, 2017). Untuk penilaian prioritas ditujukkan pada Tabel 3.

Tabel 3. Matriks Penilaian Prioritas Kepentingan Kriteria Untuk Memilih Supplier

\begin{tabular}{lccccc}
\hline Kriteria & Harga & Kualitas & $\begin{array}{c}\text { Pengi } \\
\text { riman }\end{array}$ & $\begin{array}{c}\text { Res } \\
\text { pon }\end{array}$ & Cast \\
\hline Harga & 1 & 2 & 1 & 1 & 1 \\
Kualitas & $1 / 2$ & 1 & 1 & 1 \\
Pengiriman & $1 / 4$ & $1 / 4$ & 1 & 1 \\
Respon & $1 / 3$ & $1 / 4$ & 1 & 1 & 1 \\
Cust. Care & $1 / 6$ & $1 / 4$ & 1 &
\end{tabular}

Nilai Eigen Value merupakan perkalian matriks yang diperoleh yaitu setiap baris dikalikan dengan kolom priority vector.

$\left[\begin{array}{ccccc}1 & 2 & 4 & 3 & 6 \\ 0,50 & 1 & 4 & 4 & 4 \\ 0,25 & 0,25 & 1 & 1 & 1 \\ 0,33 & 0,25 & 1 & 1 & 1 \\ 0,17 & 0,25 & 1 & 1 & 1\end{array}\right]$

Dari hasil normalisasi yang ditunjukkan Tabel 4, matriks penilaian prioritas kepentingan kriteria dalam pemilihan suppiser menunjukkan bahwa dalam memilih supplier barang consumable, prioritas pertama PT. PUSRI yaitu kriteria Harga dengan bobot 0,42 . Selanjutnya prioritas kedua yaitu kriteria Kualitas dengan bobot 0,31 , prioritas ketiga kiteria responden dengan bobot 0,10 , prioritas selanjutnya yaitu pengiriman dengan bobot 0,09 dan customer care merupakan prioritas kelima dengan bobot yang sama yaitu 0,08 .

Berdasarkan perhitungan normalisasi yang ditunjukkan pada Tabel 4, maka untuk urutan prioritas kriteria yang digunakan dalam pemilihan supplier dapat dilihat pada Tabel 5.

Tabel 5. Tabel Urutan Prioritas Kriteria

\begin{tabular}{ccc}
\hline Kriteria & Bobot & Prioritas Akhir \\
\hline Harga & 0,42 & I \\
Kualitas & 0,31 & II \\
Respon & 0,10 & III \\
Pengiriman & 0,09 & IV \\
Customer Care & 0,08 & V \\
\hline
\end{tabular}

Tabel 4. Normalisasi Matriks Penilaian Prioritas Kepentingan Kriteria Pada Pemilihan Supplier

\begin{tabular}{lccccccc}
\hline Normalisasi & Harga & Kualitas & Pengiriman & Respon & $\begin{array}{c}\text { Cust. } \\
\text { Care }\end{array}$ & Jumlah & $\begin{array}{c}\text { Priority } \\
\text { vector }\end{array}$ \\
\hline Harga & 0,44 & 0,53 & 0,36 & 0,30 & 0,46 & 2,10 & 0,42 \\
Kualitas & 0,22 & 0,27 & 0,36 & 0,40 & 0,31 & 1,56 & 0,31 \\
Pengiriman & 0,11 & 0,07 & 0,09 & 0,10 & 0,08 & 0,45 & 0,09 \\
Respon & 0,15 & 0,07 & 0,09 & 0,10 & 0,08 & 0,48 & 0,10 \\
Cust. Care & 0,07 & 0,07 & 0,09 & 0,10 & 0,08 & 0,41 & 0,08 \\
\hline Jumlah & 1,00 & 1,00 & 1,00 & 1,00 & 1,00 & &
\end{tabular}


Nilai perkalian matriks yang diperoleh yaitu setiap baris dikalikan dengan kolom priority vector. Hasil kali (HK) bernilai sebesar:

$$
\begin{aligned}
\mathrm{HK}= & (1,00 \times 0,42)+(2,00 \times 0,33)+(4,00 \times 0,09)+(3,00 \mathrm{x} \\
& 0,10)+(6,00 \times 0,08)=2,18 \\
\mathrm{HK}= & (0,50 \times 0,42)+(1,00 \times 0,33)+(4,00 \times 0,09)+(4,00 \mathrm{x} \\
& 0,10)+(4,00 \times 0,08)=1,59 \\
\mathrm{HK}= & (0,25 \times 0,42)+(0,25 \times 0.33)+(1,00 \times 0,09)+(1,00 \mathrm{x} \\
& 0,10)+(1,00 \times 0,08)=0,45 \\
\mathrm{HK}= & (0,33 \times 0,42)+(0,25 \times 0.33)+(1,00 \times 0,09)+(1,00 \mathrm{x} \\
& 0,10)+(1,00 \times 0,08)=0,49 \\
\mathrm{HK}= & (0,17 \times 0,42)+(0,25 \times 0,33)+(1,00 \times 0,09)+(1,00 \mathrm{x} \\
& 0,10)+(1,00 \times 0,08)=0,42
\end{aligned}
$$

Setelah didapat hasil perkalian matriks tingkat kepentingan antar kriteria dengan priority vector, selanjutnya dilakukan perhitungan nilai $\lambda$ max (eigen value) menggunakan rumus (7) dan hasiinga ditunjukkan pada Tabel 6 :

$$
\lambda \max =\frac{\sum a}{n}
$$

Tabel 6. Lamda matriks tingkat kepentingan antar kriteria dengan priority vector

\begin{tabular}{ccc}
\hline $\begin{array}{c}\text { Hasil Kali } \\
(\mathbf{H K})\end{array}$ & $\begin{array}{c}\text { Priority vektor } \\
(\boldsymbol{P V})\end{array}$ & $\mathbf{H K} / \mathbf{P V}$ \\
\hline $\mathbf{2 , 1 8}$ & 0,42 & 5,19 \\
$\mathbf{1 , 5 9}$ & 0,31 & 5,10 \\
$\mathbf{0 , 4 5}$ & 0,09 & 5,06 \\
$\mathbf{0 , 4 9}$ & 0,10 & 5,03 \\
$\mathbf{0 , 4 2}$ & 0,08 & 5,08 \\
& Jumlah & 25,46 \\
\hline
\end{tabular}

Maka, $\lambda \max =25,46 / 5=5,09$

Setelah mendapatkan nilai $\lambda$ max maka dilakukan perhitungan Consistensy index (CI). Consistensy index (CI) atau indeks konsistensi adalah pengukuran nilai penyimpangan dari nilai konsistensi, Indeks Konsistensi dihitung menggunakan persamaan sebagai berikut :

\begin{tabular}{|c|c|c|}
\hline Perbandingan Pasangan & $\mathbf{C R}$ & Keterangan \\
\hline Antar Kriteria & 0,02 & Konsisten \\
\hline Antar Subkriteriajugiga & 0,00 & Konsisten \\
\hline Antar Subkriteria Kualitas & 0,04 & Konsisten \\
\hline $\begin{array}{ll}\text { Antar } & \text { Subkriteria } \\
\text { Pengiriman } & \end{array}$ & 0,00 & Konsisten \\
\hline Antar Subkriteria Respon & 0,00 & Konsisten \\
\hline Subkriteria & 0,00 & Konsisten \\
\hline $\begin{array}{l}\text { Customer Care } \\
\text { Antar Alternatif Terhadap } \\
\text { Subkriteria H1 }\end{array}$ & 0,04 & Konsisten \\
\hline $\begin{array}{l}\text { Antar Alternatif Terhadap } \\
\text { Subkriteria H2 }\end{array}$ & 0,02 & Konsisten \\
\hline $\begin{array}{l}\text { Antar Alternatif Terhadap } \\
\text { Subkriteria K1 }\end{array}$ & 0,01 & Konsisten \\
\hline $\begin{array}{l}\text { Antar Alternatif Terhadap } \\
\text { Subkriteria K2 }\end{array}$ & 0,05 & Konsisten \\
\hline $\begin{array}{l}\text { Antar Alternatif Terhadap } \\
\text { Subkriteria K3 }\end{array}$ & 0,05 & Konsisten \\
\hline $\begin{array}{l}\text { Antar Alternatif Terhadap } \\
\text { Subkriteria P1 }\end{array}$ & 0,00 & Konsisten \\
\hline $\begin{array}{l}\text { Antar Alternatif Terhadap } \\
\text { Subkriteria P2 }\end{array}$ & 0,09 & Konsisten \\
\hline $\begin{array}{l}\text { Antar Alternatif Terhadap } \\
\text { Subkriteria R1 }\end{array}$ & 0,06 & Konsisten \\
\hline $\begin{array}{l}\text { Antar Alternatif Terhadap } \\
\text { Subkriteria R2 }\end{array}$ & 0,05 & Konsisten \\
\hline $\begin{array}{l}\text { Antar Alternatif Terhadap } \\
\text { Subkriteria } \mathrm{C} 1\end{array}$ & 0,00 & Konsisten \\
\hline $\begin{array}{l}\text { Antar Alternatif Terhadap } \\
\text { Subkriteria C2 }\end{array}$ & 0,00 & Konsisten \\
\hline
\end{tabular}

$$
\mathrm{CI}=\frac{\lambda \max ^{-n}}{n-1}=(5,10-\mathrm{n}) /(\mathrm{n}-1)=0,02
$$

Untuk nilai RI (Indeks Random) sudah ditentukan pada perhitungan Saaty dengan $n=5$, maka nilai $\mathrm{RI}=1,12$

$$
\text { Maka, } C R=\frac{C I}{R I}=\frac{0,02}{1,12}=0,02
$$

Karena nilai $\mathrm{CR}<0,1$ berarti preferensi responden adalah konsisten. Konsistensi untuk antar kriteria dan sub kriteria ditujukkan pada Tabel 7, yaitu :

Tabel 7. Tabel Konsistensitas Responden

Setelah perhitungan untuk semua kriteria dan alternatif, selanjutnya dilakukan perhitungan untuk mendapatkan bobot alternatif secara keseluruhan dari kriteria yang ditentukan dengan menghitung nilai global dahulu. 
Setelah mendapatkan nilai global priority, maka bobot dari tiap alternatif secara keseluruhan dapat dihitung dengan menjumlahkan nilai keseluruhan (global priority) pada tiap supplier, hasilnya ditunjukkan pada Tabel 8 .

Tabel 8. Bobot Alternatif Secara Keseluruhan

\begin{tabular}{lcc}
\multicolumn{1}{c}{ Supplier } & Bobot Akhir & Prioritas Akhir \\
\hline CV. Ditra & 0,325 & II \\
PT. Kokai & 0,455 & I \\
PD. Sinar & 0,220 & III \\
\hline
\end{tabular}

\section{KESIMPULAN}

Berdasarkan dari hasil pengolahan data dan pembahasan, implementasi metode Analytical Hierarchy Process (AHP) untuk pemilihan supplier terbaik penyedia barang consumable di departemen pengadaan barang PT. PUSRI didapatkan kesimpulan yaitu:

1. Supplier terbaik penyedia barang consumable untuk PT. PUSRI Palembang yang dipilih adalah PT. Kokai Indo Abadi dengan total bobot 0,455 atau $45,5 \%$ yang nilai bobotnya lebih tinggi dari 2 supplier lainnya.

2. PT. Kokai Indo Abadi memiliki bobot kriteria harga sebesar 0,385, kriteria kualitas sebesar 0,535 , kriteria pengiriman sebesar 0,603 , kriteria respon sebesar 0,518 dan kriteriacustoner care sebesar 0,277.

3. Kriteria - kriteria pemilihan pemasok yang tela $\mathrm{h}$ diperingkatkan berdasarkan penilaian untuk urutan prioritasnya adalah kriteria harga, kualitas, respon, pengiriman dan Customer Care.

\section{DAFTAR PUSTAKA}

[1] Andalia, W., \& Pratiwi, I. (2017). Pemilihan Katalis Menggunakan Metode Analytical Hierarchy Process (AHP) Pada Proses Pembuatan Biodiesel Reaksi Transesterifikasi. Jurnal Industrial Servicess , Vol. 3, No. 1a, 814.
[2] Anonim. (2010). Dokumen Lelang. Palembang: PT. PUSRI Persero.

[3] Astuti, J., \& Fatma, E. (2017). Evaluasi Pemilihan Penyedia Jasa Kurir Berdasarkan Metode Analytical Hierarchy Process (AHP). Jurnal Manajemen Industri dan Logistik, Vol. 1, No. 1, 28-41.

[4] Clement, R. T., \& Reilly, T. (2013). Making Hard Decisions with Decision Tools. Ohio: Cengage Learning.

[5] Dimyati, T. T., \& Dimyati, A. (2016). Operations Research : Model - Model Pengambilan Keputusan. Bandung Sinar Baru Algensindo.

[6] Fahmi, I. (2015). Teori dan Teknik Pengambilan Keputusan. Jakarta: PT Raja Grafindo Persada.

[71 Mario, H., Dennys, Caesar, S., Sulistiandi, \& Marpaung, B. (2015). Pemilihan Supplier dengan Pendekatan Metode AHP - TOPSIS dan AHP - MPE : Studi Kasus pada Perusahaan Reparasi. JUrnal Teknik dan Ilmu Komputer, Vol. 4 , No. 13, 49 - 59.

[8] Ngatawi, \& Setyaningsih, I. (2011). Analisis Pemilihan Supplier Menggunakan Metode Analytical Hierarchy Process (AHP). Jurnal Ilmiah Teknik Industri , Vol. 10, No. 1, 7-13.

[9] Prasetyo, E. B., \& Kurniati, N. (2017). Pemilihan Supplier Berdasarkan Indeks Kapabilitas dengan Karakteristik Tunggal. Jurnal Manajemen Industri dan Logistik, Vol. 1, No. 2, $113-118$.

[10] Pratiwi, I., HAK, A. A., \& Erdiyansyah, A. (2014). Usulan Model Keputusan Multikriteria untuk Pemilihan UKM Penerima Pinjaman Modal Kerja di Kota Palembang. Jurnal Desiminasi Teknologi, Vol 2, No 2, 157 - 164. 
[11] Pujawan, I. N., \& Er, M. (2017). Supply Chain Management. Yogyakarta: Penerbit Andi.

[12]Putri, Offie Nurtresnaning. (2017). Implementasi Rantai Pasok Hijau Pada Material Proyek dalam Mendukung Konstruksi Berkelanjutan. Jurnal Manajemen Industri dan Logistik, Vol. 1, No. 142 - 50.

[13] Render, B., \& Heizer, J. (2016). Manajemen Operasi : Manajemen Keberlangsungan dan Rantai Pasokan. Jakarta: Penerbit Salemba Empat.

[14] Rimatho, D., Fathurohman, Cahyadi, B., \& Sodikun. (2017). Pemilihan Supplier Rubber Parts dengan Metode Analytical Hierarchy Process di PT. XYZ. Jurnal Rekayasa Sistem Industri, Vol 6, No. 2, 93 - 104.

[15] Saaty, T. L., \& Vargas, L. G. (2012). Model, method, Concept and Application of The Analytical Hierarchy Prodess. New York: Springer Science Business Media.

[16]Widyarto, A. 2012). Supply Chain Management dalam Sistem Produksi dan Operasi Perusahaan. Benefit, Vol. 16, No. 2, 91-98. 